\title{
Constitutive Activation of the JAK/STAT and Toll-Like Receptor Signaling Pathways in Adult T-Cell Leukemia/Lymphoma
}

\author{
Takehiro Higashi, Takefumi Katsuragi, Atsushi Iwashige, \\ Hiroaki Morimoto and Junichi Tsukada \\ Cancer Chemotherapy Center and Hematology \\ University of Occupational and Environmental Health, Kitakyushu
}

Japan

\section{Introduction}

Adult T-cell leukemia/lymphoma (ATLL) caused by the retrovirus human T-cell leukemia virus type 1 (HTLV-1) infection is one of aggressive mature CD4+ T-cell neoplasms with a marked expansion of leukemic cells during the acute phase. ATLL is endemic in several regions of the world, especially in southwest Japan, the Caribbean basin, and parts of Central Africa. ATLL is divided into four clinical subtypes: acute, chronic, smoldering, and lymphoma type, based on the number of leukemic cells in peripheral blood, serum lactic acid dehydrogenase level, tumor lesions in various organs, and clinical course. The acute and lymphoma types still have an extremely poor prognosis, despite the advance in chemotherapy. Chemotherapy for ATLL has limited efficacy with median survivals of approximate one year.

The HTLV-1 genome encodes not only structural proteins, but also non-structural proteins such as Tax, Rex, p13, p12, p30, p21Rex and HTLV-1 bZIP factor (HBZ). The functional analysis of the viral proteins such as Tax has shed light on the pathogenesis of ATLL. Tax is a crucial viral protein encoded by the $\mathrm{pX}$ region, which can induce viral replication and a variety of cellular genes associated with cytokine production, inhibition of apoptosis and cell cycle dysregulation (Arima 1999, Azimi 1998, Geleziunas 1998, Kanno 1994, Mori 1996b). Tax-induced gene regulation, which is linked to malignant transformation of HTLV-1-infected T-cells, has been shown to be mediated by CREB/ATF, NF- $\mathrm{kB}$ and SRF pathways. Constitutive activation of NF- $\mathrm{BB}$ is one of common features of HTLV-1-transformed T-cells and ATLL leukemic cells, since inhibition of NF-kB activity reduces cell growth and induces apoptosis of cells, suggesting a central role of NF- $\mathrm{kB}$ in their proliferation and survival. Moreover, Tax binds to the upstream kinase, the mitogen-activated protein kinase/ERK kinase kinase- 1 and enhance its kinase activity (Harhaj 1999, Huang 2002, Jin 1999). Nevertheless, ATLL develops in a period 40 to 60 years after initial infection, indicating that the development of ATLL requires a multistep oncogenic process including accumulation of genetic mutations. HTLV-1 infection alone is not sufficient to induce neoplastic transformation of infected cells. In fact, viral gene expression is at extremely low levels in primary ATLL cells (Franchini 1984). Thus, the mechanism which develops ATLL still remains unclear. 
The general subject of signaling pathways in ATLL cells and HTLV-1-transformed cells has been covered by many excellent original reports and reviews. In this review, authors focus on recent advances of two signaling pathways in ATLL cells and HTLV-1-transformed Tcells; the JAK (Janus kinase)-STAT (signal transducer and activator of transcription) and TLR (Toll-like receptor) signaling pathways.

\section{Constitutive activation of the JAK-STAT signaling pathway in ATLL cells and HTLV-1-transformed T-cells}

STAT proteins play important roles in regulating cellular response to a variety of cytokines. STATs are latent cytosolic transcriptional factors that are activated by tyrosine phosphorylation in response to cytokines. The four mammalian members of the JAK family (Jak1, Jak2, Jak3, and Tyk2) are non-receptor tyrosine kinases functioning as signal transducers, that control activation of STATs. Jaks associate constitutively with cytokine receptors, and promote signals by phosphorylating tyrosine residues of activated receptors to allow the recruitment and activation of STAT proteins. STATs can form homo- or heterodimers in which amino acid sequence containing a phospho-tyrosine residue in one partner binds to the $\mathrm{SH} 2$ domain in the other vice versa, leading to nuclear translocation of STAT dimers and their participation in transcriptional regulation of various cytokine responsive genes (Darnell 1997, Ihle 2001, Leonard 1998).

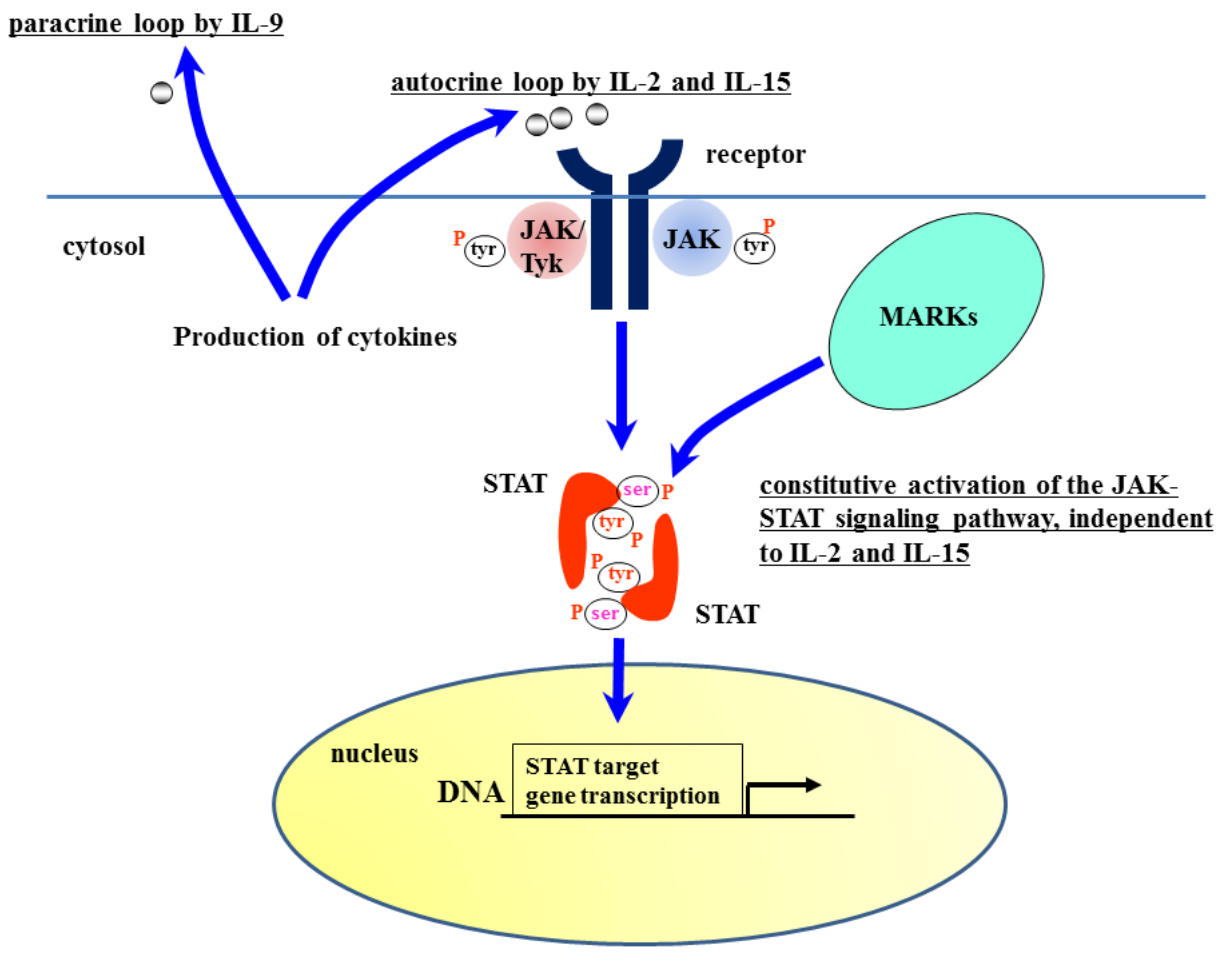

Fig. 1. The JAK-STAT signaling pathway in ATLL cells and HTLV-1-transformed T-cells. 
Recent reports have emphasized the significance of STATs in oncogenesis (Akira 1997) and leukemogenesis (Bowman 2000, Lin 2000, Levy 2000, Coffer 2000, Akira 1997). Many oncoproteins can activate STATs. In contrast to the normal cellular response, which shows rapid and transient activation of STATs, aberrant activation of JAK-STAT signaling contributes to malignant transformation. The $\mathrm{v}-\mathrm{abl}$ oncogene of the Abelson murine leukemia virus (A-MuLV) induces JAK-STAT signaling, involving Jak1 and Jak3 (Danial 1995). Interestingly, constitutive expression of a dominant-active STAT3 induces neoplastic transformation (Bromberg 1999). STAT1 and STAT5 are active in BCR-ABL-positive leukemias (Carlesso 1996, Shuai 1996, Frank 1996) and STAT1, STAT3 and STAT5 are constitutively activated in acute leukemia blasts (Gouilleux-Gruart 1996, Weber-Nordt 1996, Xia 1998, Spiekermann 2001). A constitutively active form of STAT3 can transform cells (Bromberg 1999). Constitutive activation of Jaks and STATs has been observed in murine pre-B lymphocytes transformed with the A-MuLV(Danial 1995), human B cells transformed with Epstein-Barr virus (Gouilleux-Gruart 1996) and murine erythroleukemia induced by spleen focus-forming virus (Ohashi 1995). Primary acute leukemia cells also show constitutive activation of STATs (Gouilleux-Gruart 1996, Weber-Nordt 1996, Xia 1998, Spiekermann 2001). Moreover, constitutive STAT3 activation in acute myeloid leukemia blasts has been reported to be associated with short disease-free survival, showing a prognostic significance for STAT3 (Benekli 2002).

HLTV-1 infects and immortalizes primary human T-cells. In early stage, the viral regulatory proteins Tax and Rex are involved in the up-regulation of IL-2 and IL-2R. In some ATL cases, IL-2 and IL-15 can induce growth of ATLL cells (Arima 1996, Maeda 1987, Yamada 1998) (Fig. 1). Phosphorylation of STAT3 and STAT5 in ATL cells is induced by IL-2, IL-15 and IL-21 (Ueda 2005). A paracrine growth loop that involves Tax-induced IL-9 production in ATL cells and expression of IL-9 receptor $\alpha$ on monocytes has been also observed (Chen 2008).

However, constitutive activation of the JAK-STAT pathway is generally correlated with IL-2 independence. Transformation of T-cells by HTLV-1 is associated with constitutive activation of the JAK-STAT pathway (Migone 1995, Xu 1995) (Fig1). Migone et al. (Migone 1995) demonstrated activation of Jak1, Jak3, STAT3 and STAT5 correlated with the transition from an IL-2-dependent to an IL-2-independent phase in HTLV-1-transformed cells. Spontaneous phosphorylation of Jak2 and Jak3 has also been observed in T-cells transformed with HTLV-1 (Xu 1995). Leukemia cells obtained from ATL patients also showed constitutive activation of STATs (Takemoto 1997, Tsukada 2000). Takemoto et al.(Takemoto 1997) observed constitutive activation of STAT1, STAT3 and STAT5 in leukemic cells of ATL patients, and demonstrated the association of leukemic cell proliferation with constitutive JAK-STAT activity.

In addition, no gain-of-function mutations of the Jak1 and Jak3 in primary ATLL cells has been detected (Kameda 2010). These data are contrast to the results obtained from acute Tlymphoblastic leukemia (T-ALL). Flex et al. demonstrated that JAK1 gene mutations occur in ALL and are more frequently observed among adult individuals with involvement of the T cell lineage (Flex 2008). The mutations promote gain of kinase function, and are associated with poor response to therapy and overall prognosis.

\subsection{Unique function of the Jak-STAT signaling pathway in HTLV-1-infected T-cells}

HTLV-1 infection up-regulates expression of the suppressor of cytokine signaling 1 (SOCS1). HTLV-1-induced SOCS1 inhibits the type I IFN antiviral response against HTLV-1 by 
targeting IRF3 for SOCS1-induced proteasome degradation (Oliere 2010). As an adaptor, SOCS1 brings target proteins to the elongin B/C-Cullin E3 ligase complex for ubiquitination. It may represent an immune evasion strategy and survival advantage to HTLV-1-infected cells. HTLV-1 inhibits IFN $\alpha$-induced phosphorylation of STAT2 and Tyk2 (Feng 2008). Zhang et al. further indicate that Tax interferes with IFN- $\alpha$-induced JAK-STAT signaling by completion with STAT2 for CBP/p300 binding (Zhang 2008) (Fig2).

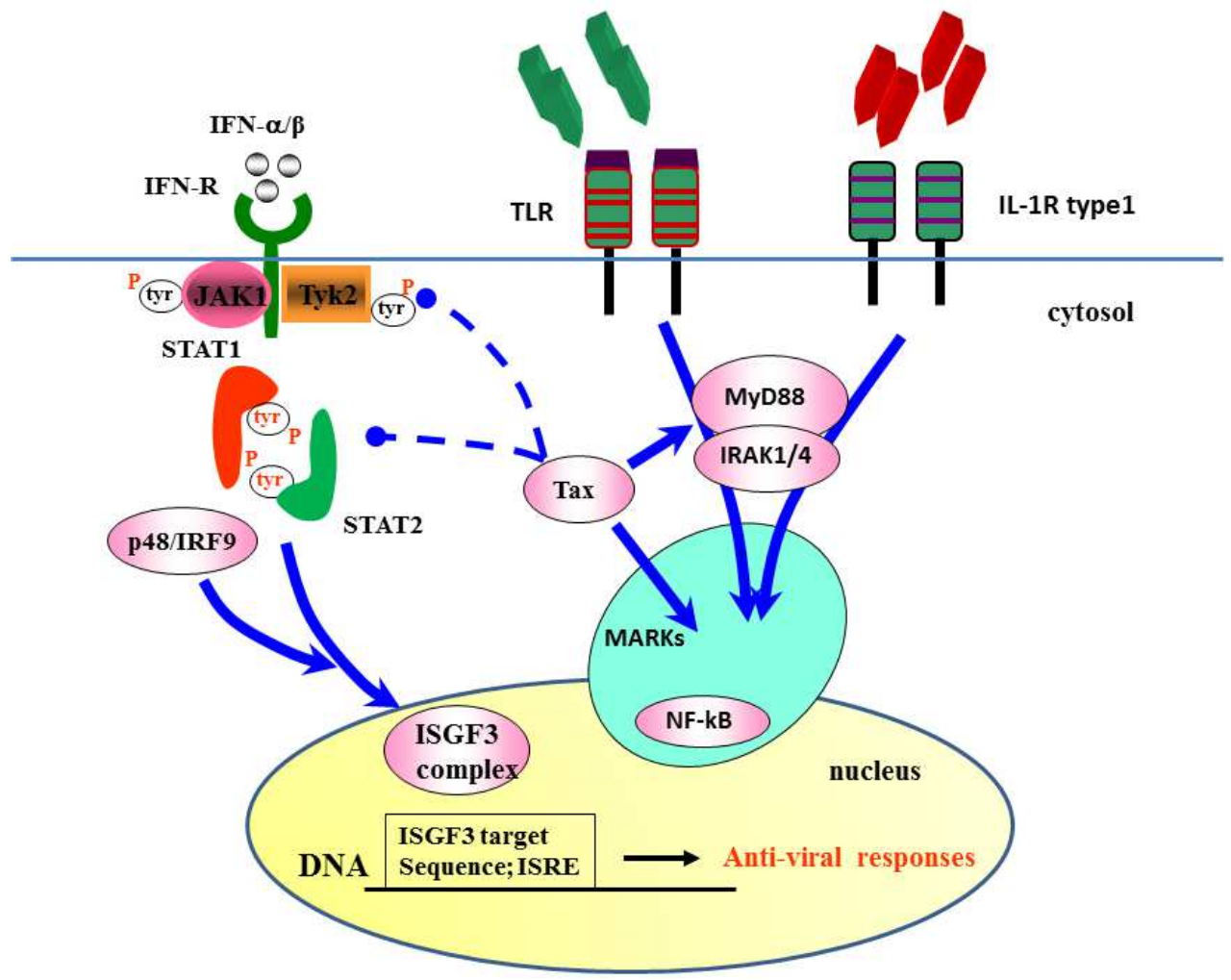

Fig. 2. Constitutive association of MyD88 with IRAK in HTLV-1-transformed T-cells.

The viral p12 protein from the pX open reading frame I (ORFI) activates Jak1/3 and STAT5, and decrease the IL-2-requirement for T-cell proliferation via binding to the cytoplasmic domain of IL-2R $\beta$ chain (Nicot 2001). Although the IL-2-Jak-STAT pathway is not associated with viral gene expression, viral RNA encapsidation, the maturation of the viral particle, cell-cell adherence or Gag polarization, p12 enhances viral transmission through activation of the IL-2-Jak-STAT pathway (Taylor 2009).

\subsubsection{Inhibition of the JAK-STAT signaling pathway in ATLL cells and HTLV-1- transformed T-cells; therapeutic approach}

Several recent studies reported inhibition of constitutive activation of the JAK-STAT signaling pathway in ATLL cells and HTLV-1-transformed T-cells. Src-related kinase Lyn 
co-immunopreciptates with Jak3 in HTLV-1-transformed cell lines HUT102, MT2, MS9 and MS68. Phosphorylation of STAT5 and STAT3 are inhibited by cell treatment with the Src kinase inhibitor PP2 or by ectopic expression of a dominant negative Lyn kinase protein (Shuh 2011). Dequelin, a naturally occurring retinoid shows anti-proliferative effect on HTLV-1-transformed cells, MT-2 and KUT-1 in part through the down-regulation of survivin and constitutive phosphorylation of STAT3. In contrast, STAT5 phosphorylation is not affected by Deguelin (Ito 2010). roscovitine, an inhibitor of cyclin-dependent kinases (CDKs) inhibits STAT5 activity required for the survival of MT-2 cells. A dominant negative STAT5 expression induces apoptosis and reduces the abundance of an anti-apoptotic protein XIAP in MT-2 cells. In ChIP assay, interaction of STAT5, but not STAT1 with the XIAP promoter has been observed. Interaction of STAT5 and PDGF $\alpha$ receptor is also prevented by roscovitine (Mohapatra 2003). Curcumin (diferuloylmethane), a naturally occurring yellow pigment isolated from the rhizomes of the plant Curcuma longa, induces apoptosis and anti-proliferative response in HTLV-1-transformed cells; MT-2, HUT102 and SLB-1. These responses are associated with inhibition of constitutive phosphorylation of Jak3, Tyk2, STAT3 and STAT5. Additionally, AP-1, especially JunD and NF-кB activity in HTLV-1-transfromed T-cells and primary ATLL cells are also inhibited by curcumin (Tomita 2006a, Tomita 2006b).

In a clinical study, Berkowitz et al. reported a single institute open-label phase II trial of intravenous daclizumab, a humanized monoclonal antibody that binds specifically to the alpha (CD25) subunit of the high-affinity IL-2R in ATLL patients. No responses were observed in aggressive acute or lymphoma type of ATLL. Partial responses were observed in 36\% of patients with chronic and smoldering ATLL (Berkowitz JL 2010).

In addition, Tasocitinib (CP-690,550), a potent and selective Jak3 inhibitor is an orally active immunosuppressant undergoing clinical trials for the treatment of autoimmune diseases and transplant rejection. It is interesting to note that Tasocitinib (CP-690,550) inhibits proliferation of peripheral blood mononuclear cells (PBMCs) from patients with chronic and smoldering form of ATLL or with HAM/TSP that manifest constitutive Jak3/STAT5 activation. This agent prolongs the survival of transgenic mice bearing human CD8 T-cell leukemia with IL-15/IL-15R autocrine growth loop required for leukemia cell survival (Ju 2011). These results suggest clinical effect of CP- 690,550 on chronic and smoldering ATLL.

\subsubsection{Constitutive tyrosine and serine phosphorylation of STAT4 in T-cells transformed with HTLV-1}

STAT4 is a crucial mediator of IL-12-stimulated gene regulation (Jacobson 1995, Bacon 1995b). In fact, the development of type-1 helper T (Th1) cells and production of IFN- $\gamma$ in response to IL-12 are disrupted in STAT4-deficient mice (Thierfelder 1996, Kaplan 1996). STAT4 is phosphorylated on tyrosine by Jak2 and Tyk2 (Bacon 1995a, Cho 1996). Moreover, IL-12 activates the p38/MKK6 signaling pathway that in turn phosphorylates STAT4 on serine (Visconti 2000). Activation of p38 and its upstream activator MKK6 is an important step for IL-12-induced STAT4 transcriptional activity (Visconti 2000, Zhang 2000). In fact, previous studies indicated that IFN- $\gamma$ production is blocked by a p38 inhibitor (Zhang 2000, Rincon 1998). Transgenic mice expressing a dominant-negative p38 showed impaired Th1 differentiation (Rincon 1998). The expression of STAT4 is observed in limited types of tissues such as testis, spleen, lung, bone marrow, thymus and muscle (Zhong 1994, Yamamoto 1994). Several T-cell lines including EL4 and DA2 contain no 
STAT4 transcripts (Yamamoto 1994). However, our study showed that tyrosinephosphorylated STAT4 was detected in HTLV-1-transformed cell lines. In addition, STAT4 protein was constitutively phosphorylated on serine as well as on tyrosine in HTLV-1-transformed cell lines (Higashi 2005).

The relevance of phosphorylation of serine in STAT4 has been recently reported. Serine phosphorylation of STAT4 is dispensable for nuclear translocation or DNA binding of STAT4, but is indispensable for its maximal transcriptional activity (Visconti 2000). Serine phosphorylation of STAT4 is required for IL-12-induced IFN- $\gamma$ production and IL-12mediated Th1 development, but not for IL-12-induced cell proliferation (Morinobu 2002). Furthermore, they have shown that serine phosphorylation of STAT4 is partially dependent on precedent tyrosine phosphorylation of STAT4, whereas tyrosine phosphorylation of STAT4 can be seen even in the absence of serine phosphorylation. In contrast, it has been shown that in leukemic cells from chronic lymphocytic leukemia patients, STAT1 and STAT3 are constitutively phosphorylated on serine, but not on tyrosine residue (Frank 1997). In the other leukemias such as AML and ALL, serine phosphorylation of the STATs was occasionally seen (Frank 1997, Hayakawa 1998). Thus, STATs may have selective effects on gene expression of leukemia cells in a manner dependent upon serine phosphorylation. We observed that IFN- $\gamma$, but not IL-12 or IFN-a was produced in HTLV-1-transformed cells.

\subsubsection{Constitutive association of MyD88 to IRAK in HTLV-1 -transformed cells}

Aberrant cytokine gene expression is a hallmark of ATLL cells (Franchini 1995, Grossman 1997, Kanno 1994, Mori 1999, Mori 1996a, Mori 1996b, Siekevitz 1987, Yamada 1996). The cytokine gene promoters possess enhancer elements for NF- $\mathrm{BB}$ and/or C/EBP $\beta$ (NF-IL6) (Azimi 1998, Faggioli 1996, Mercurio 1997, Perkins 1997, Schmitz 1995, Washizu 1998). C/EBP $\beta$ (NF-IL6), $\beta$ isoform of CCAAT/enhancer (C/EBP) family of basic-leucine zipper (bZIP) transcription factors (Tsukada 2011) was originally identified as a nuclear factor that binds to IL-1-responsive element in the IL6 gene (Akira 1990). Moreover, inhibition of NF-kB activity results in enhanced apoptosis and growth suppression of primary ATLL cells and HTLV-1-transformed T-cells, indicating a central role for NF- $\kappa \mathrm{B}$ in their survival and proliferation. Antisense oligonucleotides to RelA/p65 inhibit Tax-transformed tumor cell growth (Kitajima 1992). Sodium salicylate and cyclopentenone prostaglandins suppress proliferation of Tax-transgenic mouse spleen cells (Portis 2001). Bay-7082, an inhibitor of IкB phosphorylation induces apoptosis of HTLV-1-transformed T-cell lines and primary ATLL cells via reduced expression of the anti-apoptotic gene BCL-XL (Mori 2002). Ex vivo treatment of PBMCs with dehydroxymethylepoxyquinomicin selectively purges HTLV-1infected cells without toxicity to normal cells in HTLV-1 carriers (Watanabe 2005). More recently, activation of the classical pathway of NF- $\kappa B$ by the HBZ has been reported (Zhao 2009). HBZ does not affect the alternative pathway of NF- $\kappa B$, but induces polyubiquitination and degradation of p65. Yasunaga et al. demonstrated that ubiquitin-specific peptidase USP20 deubiquitinates TRAF6 and Tax and suppresses Tax-induced NF- $\mathrm{BB}$ activation (Yasunaga 2011). Several agents such as Bidens pilosa, a plant found in tropical and subtropical regions (Nakama 2011) and hippuristanol, an eukaryotic translation initiation inhibitor from the coral Isis hippuris (Tsumuraya 2011) also show inhibitory effect on ATLL cells through suppression of NF- $\kappa B$ actitivty. On the other hand, pan-aurora kinase inhibitor has been shown to have anti-proliferative effect on HTLV-1-transformed T-cells and primary ATLL cells through the suppression of NF- $\kappa B$ activity (Tomita 2009). However, the 
same study group reported that AZD1152, a selective inhibitor for Aurora B kinase had no effect on NF- $\kappa$ B activity in MT-4 and HUT102 cells (Tomita 2010).

The TLR comprise a subfamily within the larger superfamily of interleukin (IL) receptors, based on similarity within their cytoplasmic regions (Dunne 2003, Matsushima 2007, McGettrick 2007, Takeda 2003) The extracellular region of the IL-1 receptors (IL-1Rs) possesses three immunoglobulin-like domains, those of TLRs are characterized by the presence of 16-28 leucine-rich repeats. Engagement of IL-1R or TLR with their cognate ligands causes an adaptor protein MyD88 to be recruited to the receptor complex, which, in turn, promotes its association with the IL-1R-associated kinase (IRAK) via an interaction between the respective death domains of each molecule. This is followed by autophosphorylation of IRAK that results in dissociation from the receptor complex and its subsequent interaction with tumor-necrosis-factor (TNF) receptor-associated factor-6 (TRAF-6). Emanating from TRAF-6, two signaling pathways diverge, one eventually leading to NF- $\mathrm{B}$ activation, and another to mitogen-activated protein (MAP) kinase activation (Takeuchi 2007).

In this regard, our study demonstrated an alternative mechanism of NF- $\mathrm{BB}$ activation through the TLR signaling cascade including MyD88 and IRAK in HTLV-1--transformed Tcells and ATLL cells (Fig. 2). MyD88 and IRAK1 are constitutively active in HTLV-1transformed T-cells, but not in HTLV-1-negative T-cells (Mizobe 2007). MyD88, originally isolated as a myeloid differentiation primary response gene product, possesses its Cterminal domain, which is highly homologous to the cytoplasmic regions of the TLR family of proteins (Dunne 2003, Takeda 2003). However, unlike members of the TLR family, MyD88 contains no transmembrane domain. MyD88 acts an adaptor molecule of most TLRs and receptors for IL-1 and IL-18 to recruit IRAK to the TLR complex, thereby regulating activation of various transcription factors involved in inflammatory responses, such as NF$\kappa B$ and C/EBPß (NF-IL6) (Akira 2003a, Akira 2001, Akira 2003b, Boch 2003, Burns 1998, Dunne 2003, Jefferies 2001, Muzio 2000, O'Neill 2003, Takeda 2003).

Expression of a dominant negative MyD88 (MyD88dn) lacking its death domain (DD), MyD88dn induces apoptosis and anti-proliferative response in HTLV-1-transformed T-cells. In HTLV-1-transformed T-cells, MyD88dn protein expression inhibits constitutive activation of C/EBP $\beta$ (NF-IL6) and NF- $\mathrm{B}$, and proinflamatory cytokine gene promoters such as IL-1 $\alpha$, IFN- $\gamma$ and TNF- $\alpha$. Furthermore, Tax synergistically activates NF- $\mathrm{KB}$ with MyD88 (Mizobe 2007). The synergy may suggest ligand-independent activation of MyD88 in HTLV-1transformed cells (Fig. 2). However, NF-кB activation has been observed even in ATLL cells lacking detectable Tax expression. The mechanism for activation of NF- $\kappa \mathrm{B}$ in ATLL cells is not still clear. A recent study reported contribution of elevated CD30 expression to constitutive activation of NF- $\mathrm{KB}$ in ATLL cells (Higuchi 2005). In this regard, the noncanonical pathway for NF-кB activation, induced by B-cell activation factor (Claudio 2002, Kayagaki 2002), lymphotoxin- $\beta$ (Dejardin 2002, Saitoh 2002), CD40 (Coope 2002), TNF-like weak inducer of apoptosis (Saitoh 2003) or CD30 (Higuchi 2005) may be also involved in constitutive NF- $\kappa B$ activation in ATLL cells (Hironaka 2004).

In addition, MT-2 cells express TLR-1, 6 and 10 mRNA. Several recent reports have indicated unique expression profiles of TLRs on different subsets of T-cells. Gelman et al. (Gelman 2004) reported that TLR-3, -5 and -9 are expressed selectively on activated human $\mathrm{CD}^{+} \mathrm{T}$ cells, and that treatment of activated human $\mathrm{CD}^{+} \mathrm{T}$-cells, with dsRNA synthetic analogs, poly(I:C) and CpGoligodeoxynucleotides (CpG DNA), directly enhance their 
survival without affecting proliferation. A TLR-5 ligand flagellin and a TLR7/8 ligand R-848 promotes proliferation and to upregulate production of IFN- $\gamma$, IL-8 and IL-10, but not IL-4, in human CD4 ${ }^{+}$T-cells (Caron 2005). In particular, engagement of TLR-5 with flagellin enhances the suppressive capacity and FOXP3 expression in Treg cells (Crellin 2005). Direct modulation of Treg function by TLR2 ligands has been also reported (Oberg 2010). On the other hand, IRF-5 (P68) with a mutation of Ala to Pro at amino acid 68 (G202C; position relative to translation start codon) suppresses TLR-mediated IL-6 and IL-12p40 induction. The mutation has been identified in peripheral blood of ATLL patients (Yang 2009).

A more recent report has emphasized the significance of MyD88 in the pathogenesis and therapeutic approach for lymphoma. Ngo et al. identified a single leucine-to-proline substitution at amino acid position 265 of MyD88 protein (L265P) in 29\% of activated B-cell (ABC) subtype of diffuse large B-cell lymphoma (DLBCL) biopsy samples. This mutation occurs at an evolutionally invariant residue in the hydrophobic core and is rare or absent in the other DLBCL subtypes. They further demonstrated that in ABC DLBCL with L265P mutation, MyD88 L265P rescued the cell after MyD88 knockdown, but wild-type MyD88 was ineffective, showing that the L265P is a gain-of-function mutation and ABC DLBCL with L265P mutation depends upon the MyD88 signaling pathway. A selective small molecule inhibitor of IRAK1 and IRAK4 killed the ABC DLBCL cells. Moreover, in ABC DLBCL cell lines, MyD88 knockdown diminishes the secretion of IL-6 and IL-10 and phosphorylation of STAT3 (Ngo 2011).

\section{Conclusion}

Investigations have led to the demonstration of the several regulatory mechanisms presented in this review. Recent reports have provided detailed insight into the crucial functional roles of JAK-STAT and MyD88-TLR in ATLL. An important goal of such approaches would be the identification of unique targets for clinical intervention. The fact that the two signaling pathway are attractive targets for leukemia therapies further argues the importance of constitutive activation of these factors in ATLL cells.

\section{References}

Akira, S (1997) IL-6-regulated transcription factors. Int J Biochem Cell Biol, 29, 12, 1401-18.

Akira, S (2003) Toll-like receptor signaling. J Biol Chem, 278, 40, 38105-8, 0021-9258.

Akira, S, Isshiki, H, Sugita, T, Tanabe, O, Kinoshita, S, Nishio, Y, Nakajima, T, Hirano, T \& Kishimoto, T (1990) A nuclear factor for IL-6 expression (NF-IL6) is a member of a C/EBP family. EMBO J, 9, 6, 1897-906, 0261-4189.

Akira, S, Takeda, K \& Kaisho, T (2001) Toll-like receptors: critical proteins linking innate and acquired immunity. Nat Immunol, 2, 8, 675-80, 1529-2908.

Akira, S, Yamamoto, M \& Takeda, K (2003) Role of adapters in Toll-like receptor signalling. Biochem Soc Trans, 31, Pt 3, 637-42, 0300-5127.

Arima, N, Hidaka, S, Fujiwara, H, Matsushita, K, Ohtsubo, H, Arimura, K, Kukita, T, Fukumori, J \& Tanaka, H (1996) Relation of autonomous and interleukin-2responsive growth of leukemic cells to survival in adult T-cell leukemia. Blood, 87, 7, 2900-4, 0006-4971.

Arima, N, Matsushita, K, Obata, H, Ohtsubo, H, Fujiwara, H, Arimura, K, Kukita, T, Suruga, Y, Wakamatsu, S, Hidaka, S \& Tei, C (1999) NF-кB involvement in the activation of 
primary adult T-cell leukemia cells and its clinical implications. Exp Hematol, 27, 7, 1168-75, 0301-472X.

Azimi, N, Brown, K, Bamford, RN, Tagaya, Y, Siebenlist, U \& Waldmann, TA (1998) Human $\mathrm{T}$ cell lymphotropic virus type I Tax protein trans-activates interleukin 15 gene transcription through an NF-кB site. Proc Natl Acad Sci U S A, 95, 5, 2452-7, 0027-8424

Bacon, CM, McVicar, DW, Ortaldo, JR, Rees, RC, O'Shea, JJ \& Johnston, JA (1995a) Interleukin 12 (IL-12) induces tyrosine phosphorylation of JAK2 and TYK2: differential use of Janus family tyrosine kinases by IL-2 and IL-12. J Exp Med, 181, 1, 399-404.

Bacon, CM, Petricoin, EF, 3rd, Ortaldo, JR, Rees, RC, Larner, AC, Johnston, JA \& O'Shea, JJ (1995b) Interleukin 12 induces tyrosine phosphorylation and activation of STAT4 in human lymphocytes. Proc Natl Acad Sci U S A, 92, 16, 7307-11.

Benekli, M, Xia, Z, Donohue, KA, Ford, LA, Pixley, LA, Baer, MR, Baumann, H \& Wetzler, M (2002) Constitutive activity of signal transducer and activator of transcription 3 protein in acute myeloid leukemia blasts is associated with short disease-free survival. Blood, 99, 1, 252-7.

Berkowitz JL, JJ, Stewart DM, Fioravanti S, Jaffe ES, Fleisher TA, Urquhart N,Wharfe JH, Waldmann TA, Morris JC (2010) Phase II trial of daclizumab in human T-cell lymphotropic virus type-1 (HTLV-1)-associated adult T-cell leukemia/lymphoma (ATL). J Clin Oncol, 28, 15s, suppl; abstr 8043.

Boch, JA, Yoshida, Y, Koyama, Y, Wara-Aswapati, N, Peng, H, Unlu, S \& Auron, PE (2003) Characterization of a cascade of protein interactions initiated at the IL-1 receptor. Biochem Biophys Res Commun, 303, 2, 525-31, 0006-291X.

Bowman, T, Garcia, R, Turkson, J \& Jove, R (2000) STATs in oncogenesis. Oncogene, 19, 21, 2474-88.

Bromberg, JF, Wrzeszczynska, MH, Devgan, G, Zhao, Y, Pestell, RG, Albanese, C \& Darnell, JE, Jr. (1999) Stat3 as an oncogene. Cell, 98, 3, 295-303.

Burns, K, Martinon, F, Esslinger, C, Pahl, H, Schneider, P, Bodmer, JL, Di Marco, F, French, L \& Tschopp, J (1998) MyD88, an adapter protein involved in interleukin-1 signaling. J Biol Chem, 273, 20, 12203-9, 0021-9258. .

Carlesso, N, Frank, DA \& Griffin, JD (1996) Tyrosyl phosphorylation and DNA binding activity of signal transducers and activators of transcription (STAT) proteins in hematopoietic cell lines transformed by Bcr/Abl. J Exp Med, 183, 3, 811-20.

Caron, G, Duluc, D, Fremaux, I, Jeannin, P, David, C, Gascan, H \& Delneste, Y (2005) Direct stimulation of human T cells via TLR5 and TLR7/8: flagellin and R-848 up-regulate proliferation and IFN- $\gamma$ production by memory CD4+ T cells. J Immunol, 175, 3, 1551-7, 0022-1767..

Chen, J, Petrus, M, Bryant, BR, Phuc Nguyen, V, Stamer, M, Goldman, CK, Bamford, R, Morris, JC, Janik, JE \& Waldmann, TA (2008) Induction of the IL-9 gene by HTLV-I Tax stimulates the spontaneous proliferation of primary adult T-cell leukemia cells by a paracrine mechanism. Blood, 111, 10, 5163-72, 1528-0020.

Cho, SS, Bacon, CM, Sudarshan, C, Rees, RC, Finbloom, D, Pine, R \& O'Shea, JJ (1996) Activation of STAT4 by IL-12 and IFN- $\alpha$ : evidence for the involvement of ligandinduced tyrosine and serine phosphorylation. J Immunol, 157, 11, 4781-9. 
Claudio, E, Brown, K, Park, S, Wang, H \& Siebenlist, U (2002) BAFF-induced NEMOindependent processing of NF-кB2 in maturing B cells. Nat Immunol, 3, 10, 958-65, 1529-2908.

Coffer, PJ, Koenderman, L \& de Groot, RP (2000) The role of STATs in myeloid differentiation and leukemia. Oncogene, 19, 21, 2511-22.

Coope, HJ, Atkinson, PG, Huhse, B, Belich, M, Janzen, J, Holman, MJ, Klaus, GG, Johnston, LH \& Ley, SC (2002) CD40 regulates the processing of NF-kB2 p100 to p52. EMBO J, 21, 20, 5375-85, 0261-4189.

Crellin, NK, Garcia, RV, Hadisfar, O, Allan, SE, Steiner, TS \& Levings, MK (2005) Human CD4+ $\mathrm{T}$ cells express TLR5 and its ligand flagellin enhances the suppressive capacity and expression of FOXP3 in CD4+CD25+ T regulatory cells. J Immunol, $175,12,8051-9,0022-1767$.

Danial, NN, Pernis, A \& Rothman, PB (1995) Jak-STAT signaling induced by the v-abl oncogene. Science, 269, 5232, 1875-7.

Darnell, JE, Jr. (1997) STATs and gene regulation. Science, 277, 5332, 1630-5.

Dejardin, E, Droin, NM, Delhase, M, Haas, E, Cao, Y, Makris, C, Li, ZW, Karin, M, Ware, CF \& Green, DR (2002) The lymphotoxin-beta receptor induces different patterns of gene expression via two NF-кB pathways. Immunity, 17, 4, 525-35, 1074-7613.

Dunne, A \& O'Neill, LA (2003) The interleukin-1 receptor/Toll-like receptor superfamily: signal transduction during inflammation and host defense. Sci STKE, 2003, 171, re3, 1525-8882.

Faggioli, L, Costanzo, C, Merola, M, Bianchini, E, Furia, A, Carsana, A \& Palmieri, M (1996) Nuclear factor $\kappa B(\mathrm{NF}-\kappa \mathrm{B})$, nuclear factor interleukin-6 (NFIL-6 or C/EBP $\beta$ ) and nuclear factor interleukin-6 $\beta$ (NFIL6- $\beta$ or C/EBP8) are not sufficient to activate the endogenous interleukin- 6 gene in the human breast carcinoma cell line MCF-7. Comparative analysis with MDA-MB-231 cells, an interleukin-6-expressing human breast carcinoma cell line. Eur J Biochem, 239, 3, 624-31, 0014-2956.

Feng, X \& Ratner, L (2008) Human T-cell leukemia virus type 1 blunts signaling by interferon $\alpha$. Virology, 374, 1, 210-6, 0042-6822.

Flex, E, Petrangeli, V, Stella, L, Chiaretti, S, Hornakova, T, Knoops, L, Ariola, C, Fodale, V, Clappier, E, Paoloni, F, Martinelli, S, Fragale, A, Sanchez, M, Tavolaro, S, Messina, M, Cazzaniga, G, Camera, A, Pizzolo, G, Tornesello, A, Vignetti, M, Battistini, A, Cave, H, Gelb, BD, Renauld, JC, Biondi, A, Constantinescu, SN, Foa, R \& Tartaglia, M (2008) Somatically acquired JAK1 mutations in adult acute lymphoblastic leukemia. J Exp Med, 205, 4, 751-8, 1540-9538.

Franchini, G (1995) Molecular mechanisms of human T-cell leukemia/lymphotropic virus type I infection. Blood, 86, 10, 3619-39, 0006-4971.

Franchini, G, Wong-Staal, F \& Gallo, RC (1984) Human T-cell leukemia virus (HTLV-I) transcripts in fresh and cultured cells of patients with adult T-cell leukemia. Proc Natl Acad Sci U S A, 81, 19, 6207-11, 0027-8424.

Frank, DA, Mahajan, S \& Ritz, J (1997) B lymphocytes from patients with chronic lymphocytic leukemia contain signal transducer and activator of transcription (STAT) 1 and STAT3 constitutively phosphorylated on serine residues. J Clin Invest, $100,12,3140-8$. 
Frank, DA \& Varticovski, L (1996) BCR/abl leads to the constitutive activation of Stat proteins, and shares an epitope with tyrosine phosphorylated Stats. Leukemia, 10, 11, 1724-30.

Geleziunas, R, Ferrell, S, Lin, X, Mu, Y, Cunningham, ET, Jr., Grant, M, Connelly, MA, Hambor, JE, Marcu, KB \& Greene, WC (1998) Human T-cell leukemia virus type 1

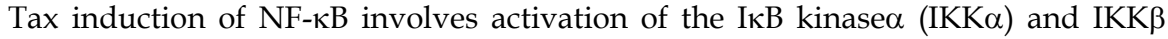
cellular kinases. Mol Cell Biol, 18, 9, 5157-65, 0270-7306.

Gelman, AE, Zhang, J, Choi, Y \& Turka, LA (2004) Toll-like receptor ligands directly promote activated CD4+ T cell survival. J Immunol, 172, 10, 6065-73, 0022-1767.

Gouilleux-Gruart, V, Gouilleux, F, Desaint, C, Claisse, JF, Capiod, JC, Delobel, J, WeberNordt, R, Dusanter-Fourt, I, Dreyfus, F, Groner, B \& Prin, L (1996) STAT-related transcription factors are constitutively activated in peripheral blood cells from acute leukemia patients. Blood, 87, 5, 1692-7.

Grossman, WJ \& Ratner, L (1997) Cytokine expression and tumorigenicity of large granular lymphocytic leukemia cells from mice transgenic for the tax gene of human T-cell leukemia virus type I. Blood, 90, 2, 783-94, 0006-4971.

Harhaj, EW \& Sun, SC (1999) IKK $\gamma$ serves as a docking subunit of the IкB kinase (IKK) and mediates interaction of IKK with the human T-cell leukemia virus Tax protein. $J$ Biol Chem, 274, 33, 22911-4, 0021-9258.

Hayakawa, F, Towatari, M, Iida, H, Wakao, H, Kiyoi, H, Naoe, T \& Saito, H (1998) Differential constitutive activation between STAT-related proteins and MAP kinase in primary acute myelogenous leukaemia. Br J Haematol, 101, 3, 521-8.

Higashi, T, Tsukada, J, Yoshida, Y, Mizobe, T, Mouri, F, Minami, Y, Morimoto, H \& Tanaka, Y (2005) Constitutive tyrosine and serine phosphorylation of STAT4 in T-cells transformed with HTLV-I. Genes Cells, 10, 12, 1153-62, 1356-9597.

Higuchi, M, Matsuda, T, Mori, N, Yamada, Y, Horie, R, Watanabe, T, Takahashi, M, Oie, M \& Fujii, M (2005) Elevated expression of CD30 in adult T-cell leukemia cell lines: possible role in constitutive NF-kB activation. Retrovirology, 2, 29, 1742-4690.

Hironaka, N, Mochida, K, Mori, N, Maeda, M, Yamamoto, N \& Yamaoka, S (2004) Taxindependent constitutive IкB kinase activation in adult T-cell leukemia cells. Neoplasia, 6, 3, 266-78, 1522-8002.

Huang, GJ, Zhang, ZQ \& Jin, DY (2002) Stimulation of IKK- $\gamma$ oligomerization by the human T-cell leukemia virus oncoprotein Tax. FEBS Lett, 531, 3, 494-8, 0014-5793.

Ihle, JN (2001) The Stat family in cytokine signaling. Curr Opin Cell Biol, 13, 2, 211-7.

Ito, S, Oyake, T, Murai, K \& Ishida, Y (2010) Deguelin suppresses cell proliferation via the inhibition of survivin expression and STAT3 phosphorylation in HTLV-1transformed T cells. Leuk Res, 34, 3, 352-7, 1873-5835.

Jacobson, NG, Szabo, SJ, Weber-Nordt, RM, Zhong, Z, Schreiber, RD, Darnell, JE, Jr. \& Murphy, KM (1995) Interleukin 12 signaling in T helper type 1 (Th1) cells involves tyrosine phosphorylation of signal transducer and activator of transcription (Stat)3 and Stat4. J Exp Med, 181, 5, 1755-62.

Jefferies, C, Bowie, A, Brady, G, Cooke, EL, Li, X \& O'Neill, LA (2001) Transactivation by the p65 subunit of NF- $\mathrm{KB}$ in response to interleukin-1 (IL-1) involves MyD88, IL-1 receptor-associated kinase 1, TRAF-6, and Rac1. Mol Cell Biol, 21, 14, 4544-52, 0270-7306. 
Jin, DY, Giordano, V, Kibler, KV, Nakano, H \& Jeang, KT (1999) Role of adapter function in oncoprotein-mediated activation of NF-кB. Human T-cell leukemia virus type I Tax interacts directly with IкB kinase $\gamma$. J Biol Chem, 274, 25, 17402-5, 0021-9258.

Ju, W, Zhang, M, Jiang, JK, Thomas, CJ, Oh, U, Bryant, BR, Chen, J, Sato, N, Tagaya, Y, Morris, JC, Janik, JE, Jacobson, S \& Waldmann, TA (2011) CP-690,550, a therapeutic agent, inhibits cytokine-mediated Jak3 activation and proliferation of $\mathrm{T}$ cells from patients with ATL and HAM/TSP. Blood, 117, 6, 1938-46, 1528-0020.

Kameda, T, Shide, K, Shimoda, HK, Hidaka, T, Kubuki, Y, Katayose, K, Taniguchi, Y, Sekine, M, Kamiunntenn, A, Maeda, K, Nagata, K, Matsunaga, T \& Shimoda, K (2010) Absence of gain-of-function JAK1 and JAK3 mutations in adult $\mathrm{T}$ cell leukemia/lymphoma. Int J Hematol, 92, 2, 320-5, 1865-3774.

Kanno, T, Brown, K, Franzoso, G \& Siebenlist, U (1994) Kinetic analysis of human T-cell leukemia virus type I Tax-mediated activation of NF-кB. Mol Cell Biol, 14, 10, 644351, 0270-7306.

Kaplan, MH, Sun, YL, Hoey, T \& Grusby, MJ (1996) Impaired IL-12 responses and enhanced development of Th2 cells in Stat4-deficient mice. Nature, 382, 6587, 174-7.

Kayagaki, N, Yan, M, Seshasayee, D, Wang, H, Lee, W, French, DM, Grewal, IS, Cochran, AG, Gordon, NC, Yin, J, Starovasnik, MA \& Dixit, VM (2002) BAFF/BLyS receptor 3 binds the $B$ cell survival factor BAFF ligand through a discrete surface loop and promotes processing of NF-кB2. Immunity, 17, 4, 515-24, 1074-7613.

Kitajima, I, Shinohara, T, Bilakovics, J, Brown, DA, Xu, X \& Nerenberg, M (1992) Ablation of transplanted HTLV-I Tax-transformed tumors in mice by antisense inhibition of NF-кB. Science, 258, 5089, 1792-5, 0036-8075.

Leonard, WJ \& O'Shea, JJ (1998) Jaks and STATs: biological implications. Annu Rev Immunol, $16,293-322$.

Levy, DE \& Gilliland, DG (2000) Divergent roles of STAT1 and STAT5 in malignancy as revealed by gene disruptions in mice. Oncogene, 19, 21, 2505-10.

Lin, TS, Mahajan, S \& Frank, DA (2000) STAT signaling in the pathogenesis and treatment of leukemias. Oncogene, 19, 21, 2496-504.

Maeda, M, Arima, N, Daitoku, Y, Kashihara, M, Okamoto, H, Uchiyama, T, Shirono, K, Matsuoka, M, Hattori, T, Takatsuki, K \& et al. (1987) Evidence for the interleukin-2 dependent expansion of leukemic cells in adult T cell leukemia. Blood, 70, 5, 1407$11,0006-4971$.

Matsushima, N, Tanaka, T, Enkhbayar, P, Mikami, T, Taga, M, Yamada, K \& Kuroki, Y (2007) Comparative sequence analysis of leucine-rich repeats (LRRs) within vertebrate toll-like receptors. BMC Genomics, 8, 124, 1471-2164.

McGettrick, AF \& O'Neill, LA (2007) Toll-like receptors: key activators of leucocytes and regulator of haematopoiesis. Br J Haematol, 139, 2, 185-93, 0007-1048.

Mercurio, F, Zhu, H, Murray, BW, Shevchenko, A, Bennett, BL, Li, J, Young, DB, Barbosa, M, Mann, M, Manning, A \& Rao, A (1997) IKK-1 and IKK-2: cytokine-activated IкB kinases essential for NF-кB activation. Science, 278, 5339, 860-6, 0036-8075.

Migone, TS, Lin, JX, Cereseto, A, Mulloy, JC, O'Shea, JJ, Franchini, G \& Leonard, WJ (1995) Constitutively activated Jak-STAT pathway in T cells transformed with HTLV-I. Science, 269, 5220, 79-81. 
Mizobe, T, Tsukada, J, Higashi, T, Mouri, F, Matsuura, A, Tanikawa, R, Minami, Y, Yoshida, Y \& Tanaka, Y (2007) Constitutive association of MyD88 to IRAK in HTLV-Itransformed T cells. Exp Hematol, 35, 12, 1812-22, 0301-472X.

Mohapatra, S, Chu, B, Wei, S, Djeu, J, Epling-Burnette, PK, Loughran, T, Jove, R \& Pledger, WJ (2003) Roscovitine inhibits STAT5 activity and induces apoptosis in the human leukemia virus type 1-transformed cell line MT-2. Cancer Res, 63, 23, 8523-30, 0008-5472.

Mori, N, Fujii, M, Ikeda, S, Yamada, Y, Tomonaga, M, Ballard, DW \& Yamamoto, N (1999) Constitutive activation of NF-кB in primary adult T-cell leukemia cells. Blood, 93, 7, 2360-8, 0006-4971.

Mori, N, Gill, PS, Mougdil, T, Murakami, S, Eto, S \& Prager, D (1996) Interleukin-10 gene expression in adult T-cell leukemia. Blood, 88, 3, 1035-45, 0006-4971.

Mori, N \& Prager, D (1996) Transactivation of the interleukin-1alpha promoter by human Tcell leukemia virus type I and type II Tax proteins. Blood, 87, 8, 3410-7, 0006-4971.

Mori, N, Yamada, Y, Ikeda, S, Yamasaki, Y, Tsukasaki, K, Tanaka, Y, Tomonaga, M, Yamamoto, N \& Fujii, M (2002) Bay 11-7082 inhibits transcription factor NF-אB and induces apoptosis of HTLV-I-infected T-cell lines and primary adult T-cell leukemia cells. Blood, 100, 5, 1828-34, 0006-4971.

Morinobu, A, Gadina, M, Strober, W, Visconti, R, Fornace, A, Montagna, C, Feldman, GM, Nishikomori, R \& O'Shea, JJ (2002) STAT4 serine phosphorylation is critical for IL12-induced IFN- $\gamma$ production but not for cell proliferation. Proc Natl Acad Sci U S A, 99, 19, 12281-6.

Muzio, M, Polentarutti, N, Bosisio, D, Manoj Kumar, PP \& Mantovani, A (2000) Toll-like receptor family and signalling pathway. Biochem Soc Trans, 28, 5, 563-6, 0300-5127.

Nakama, S, Ishikawa, C, Nakachi, S \& Mori, N (2011) Anti-adult T-cell leukemia effects of Bidens pilosa. Int J Oncol, 38, 4, 1163-73, 1791-2423.

Ngo, VN, Young, RM, Schmitz, R, Jhavar, S, Xiao, W, Lim, KH, Kohlhammer, H, Xu, W, Yang, Y, Zhao, H, Shaffer, AL, Romesser, P, Wright, G, Powell, J, Rosenwald, A, Muller-Hermelink, HK, Ott, G, Gascoyne, RD, Connors, JM, Rimsza, LM, Campo, E, Jaffe, ES, Delabie, J, Smeland, EB, Fisher, RI, Braziel, RM, Tubbs, RR, Cook, JR, Weisenburger, DD, Chan, WC \& Staudt, LM (2011) Oncogenically active MYD88 mutations in human lymphoma. Nature, 470, 7332, 115-9, 1476-4687 .

Nicot, C, Mulloy, JC, Ferrari, MG, Johnson, JM, Fu, K, Fukumoto, R, Trovato, R, Fullen, J, Leonard, WJ \& Franchini, G (2001) HTLV-1 p12(I) protein enhances STAT5 activation and decreases the interleukin-2 requirement for proliferation of primary human peripheral blood mononuclear cells. Blood, 98, 3, 823-9, 0006-4971.

O'Neill, LA (2003) The role of MyD88-like adapters in Toll-like receptor signal transduction. Biochem Soc Trans, 31, Pt 3, 643-7, 0300-5127.

Oberg, HH, Ly, TT, Ussat, S, Meyer, T, Kabelitz, D \& Wesch, D (2010) Differential but direct abolishment of human regulatory $\mathrm{T}$ cell suppressive capacity by various TLR2 ligands. J Immunol, 184, 9, 4733-40, 1550-6606.

Ohashi, T, Masuda, M \& Ruscetti, SK (1995) Induction of sequence-specific DNA-binding factors by erythropoietin and the spleen focus-forming virus. Blood, 85, 6, 1454-62.

Oliere, S, Hernandez, E, Lezin, A, Arguello, M, Douville, R, Nguyen, TL, Olindo, S, Panelatti, G, Kazanji, M, Wilkinson, P, Sekaly, RP, Cesaire, R \& Hiscott, J (2010) 
HTLV-1 evades type I interferon antiviral signaling by inducing the suppressor of cytokine signaling 1 (SOCS1). PLoS Pathog, 6, 11, e1001177, 1553-7374.

Perkins, ND (1997) Achieving transcriptional specificity with NF-кB. Int J Biochem Cell Biol, $29,12,1433-48,1357-2725$.

Portis, T, Harding, JC \& Ratner, L (2001) The contribution of NF- $\kappa B$ activity to spontaneous proliferation and resistance to apoptosis in human T-cell leukemia virus type 1 Taxinduced tumors. Blood, 98, 4, 1200-8, 0006-4971.

Rincon, M, Enslen, H, Raingeaud, J, Recht, M, Zapton, T, Su, MS, Penix, LA, Davis, RJ \& Flavell, RA (1998) Interferon- $\gamma$ expression by Th1 effector $\mathrm{T}$ cells mediated by the p38 MAP kinase signaling pathway. Embo J, 17, 10, 2817-29.

Saitoh, T, Nakano, H, Yamamoto, N \& Yamaoka, S (2002) Lymphotoxin-beta receptor mediates NEMO-independent NF-кB activation. FEBS Lett, 532, 1-2, 45-51, 00145793.

Saitoh, T, Nakayama, M, Nakano, H, Yagita, H, Yamamoto, N \& Yamaoka, S (2003) TWEAK

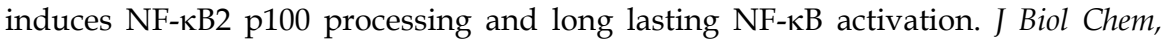
278, 38, 36005-12, 0021-9258.

Schmitz, ML \& Baeuerle, PA (1995) Multi-step activation of NF-кB/Rel transcription factors. Immunobiology, 193, 2-4, 116-27, 0171-2985.

Shuai, K, Halpern, J, ten Hoeve, J, Rao, X \& Sawyers, CL (1996) Constitutive activation of STAT5 by the BCR-ABL oncogene in chronic myelogenous leukemia. Oncogene, 13, 2, 247-54.

Shuh, M, Morse, BA, Heidecker, G \& Derse, D (2011) Association of SRC-related kinase lyn with the interleukin-2 receptor and its role in maintaining constitutive phosphorylation of Jak/STAT in human T-cell leukemia virus type 1-transformed T cells. J Virol, 85, 9, 4623-7, 1098-5514 .

Siekevitz, M, Feinberg, MB, Holbrook, N, Wong-Staal, F \& Greene, WC (1987) Activation of interleukin 2 and interleukin 2 receptor (Tac) promoter expression by the transactivator (tat) gene product of human T-cell leukemia virus, type I. Proc Natl Acad Sci U S A, 84, 15, 5389-93, 0027-8424.

Spiekermann, K, Biethahn, S, Wilde, S, Hiddemann, W \& Alves, F (2001) Constitutive activation of STAT transcription factors in acute myelogenous leukemia. Eur J Haematol, 67, 2, 63-71.

Takeda, K, Kaisho, T \& Akira, S (2003) Toll-like receptors. Annu Rev Immunol, 21, 335-76, 0732-0582.

Takemoto, S, Mulloy, JC, Cereseto, A, Migone, TS, Patel, BK, Matsuoka, M, Yamaguchi, K, Takatsuki, K, Kamihira, S, White, JD, Leonard, WJ, Waldmann, T \& Franchini, G (1997) Proliferation of adult T cell leukemia/lymphoma cells is associated with the constitutive activation of JAK/STAT proteins. Proc Natl Acad Sci U S A, 94, 25, 13897-902.

Takeuchi, O \& Akira, S (2007) Signaling pathways activated by microorganisms. Curr Opin Cell Biol, 19, 2, 185-91, 0955-0674.

Taylor, JM, Brown, M, Nejmeddine, M, Kim, KJ, Ratner, L, Lairmore, M \& Nicot, C (2009) Novel role for interleukin-2 receptor-Jak signaling in retrovirus transmission. $J$ Virol, 83, 22, 11467-76, 1098-5514.

Thierfelder, WE, van Deursen, JM, Yamamoto, K, Tripp, RA, Sarawar, SR, Carson, RT, Sangster, MY, Vignali, DA, Doherty, PC, Grosveld, GC \& Ihle, JN (1996) 
Requirement for Stat4 in interleukin-12-mediated responses of natural killer and $\mathrm{T}$ cells. Nature, 382, 6587, 171-4.

Tomita, M, Kawakami, H, Uchihara, JN, Okudaira, T, Masuda, M, Takasu, N, Matsuda, T, Ohta, T, Tanaka, Y \& Mori, N (2006a) Curcumin suppresses constitutive activation of AP-1 by downregulation of JunD protein in HTLV-1-infected T-cell lines. Leuk Res, 30, 3, 313-21, 0145-2126.

Tomita, M, Kawakami, H, Uchihara, JN, Okudaira, T, Masuda, M, Takasu, N, Matsuda, T, Ohta, T, Tanaka, Y, Ohshiro, K \& Mori, N (2006b) Curcumin (diferuloylmethane) inhibits constitutive active NF- $\kappa \mathrm{B}$, leading to suppression of cell growth of human T-cell leukemia virus type I-infected T-cell lines and primary adult T-cell leukemia cells. Int J Cancer, 118, 3, 765-72, 0020-7136.

Tomita, M, Tanaka, Y \& Mori, N (2010) Aurora kinase inhibitor AZD1152 negatively affects the growth and survival of HTLV-1-infected T lymphocytes in vitro. Int J Cancer, 127, 7, 1584-94, 1097-0215.

Tomita, M, Toyota, M, Ishikawa, C, Nakazato, T, Okudaira, T, Matsuda, T, Uchihara, JN, Taira, N, Ohshiro, K, Senba, M, Tanaka, Y, Ohshima, K, Saya, H, Tokino, T \& Mori, N (2009) Overexpression of Aurora A by loss of CHFR gene expression increases the growth and survival of HTLV-1-infected T cells through enhanced NF- $\kappa B$ activity. Int J Cancer, 124, 11, 2607-15, 1097-0215.

Tsukada, J, Toda, Y, Misago, M, Tanaka, Y, Auron, PE \& Eto, S (2000) Constitutive activation of LIL-Stat in adult T-cell leukemia cells. Blood, 95, 8, 2715-8.

Tsukada, J, Yoshida, Y, Kominato, Y \& Auron, PE (2011) The CCAAT/enhancer (C/EBP) family of basic-leucine zipper (bZIP) transcription factors is a multifaceted highlyregulated system for gene regulation. Cytokine, 54, 1, 6-19, 1096-0023.

Tsumuraya, T, Ishikawa, C, Machijima, Y, Nakachi, S, Senba, M, Tanaka, J \& Mori, N (2011) Effects of hippuristanol, an inhibitor of eIF4A, on adult T-cell leukemia. Biochem Pharmacol, 81, 6, 713-22, 1873-2968.

Ueda, M, Imada, K, Imura, A, Koga, H, Hishizawa, M \& Uchiyama, T (2005) Expression of functional interleukin-21 receptor on adult T-cell leukaemia cells. Br J Haematol, 128, 2, 169-76, 0007-1048.

Visconti, R, Gadina, M, Chiariello, M, Chen, EH, Stancato, LF, Gutkind, JS \& O'Shea, JJ (2000) Importance of the MKK6/p38 pathway for interleukin-12-induced STAT4 serine phosphorylation and transcriptional activity. Blood, 96, 5, 1844-52.

Washizu, J, Nishimura, H, Nakamura, N, Nimura, Y \& Yoshikai, Y (1998) The NF-кB binding site is essential for transcriptional activation of the IL-15 gene. Immunogenetics, 48, 1, 1-7, 0093-7711.

Watanabe, M, Ohsugi, T, Shoda, M, Ishida, T, Aizawa, S, Maruyama-Nagai, M, Utsunomiya, A, Koga, S, Yamada, Y, Kamihira, S, Okayama, A, Kikuchi, H, Uozumi, K, Yamaguchi, K, Higashihara, M, Umezawa, K, Watanabe, T \& Horie, R (2005) Dual targeting of transformed and untransformed HTLV-1-infected T cells by DHMEQ, a potent and selective inhibitor of NF- $\mathrm{BB}$, as a strategy for chemoprevention and therapy of adult T-cell leukemia. Blood, 106, 7, 2462-71, 0006-4971.

Weber-Nordt, RM, Egen, C, Wehinger, J, Ludwig, W, Gouilleux-Gruart, V, Mertelsmann, R \& Finke, J (1996) Constitutive activation of STAT proteins in primary lymphoid and myeloid leukemia cells and in Epstein-Barr virus (EBV)-related lymphoma cell lines. Blood, 88, 3, 809-16. 
Xia, Z, Baer, MR, Block, AW, Baumann, H \& Wetzler, M (1998) Expression of signal transducers and activators of transcription proteins in acute myeloid leukemia blasts. Cancer Res, 58, 14, 3173-80.

$\mathrm{Xu}, \mathrm{X}$, Kang, SH, Heidenreich, O, Okerholm, M, O'Shea, JJ \& Nerenberg, MI (1995) Constitutive activation of different Jak tyrosine kinases in human $\mathrm{T}$ cell leukemia virus type 1 (HTLV-1) tax protein or virus-transformed cells. J Clin Invest, 96, 3, 1548-55.

Yamada, Y, Ohmoto, Y, Hata, T, Yamamura, M, Murata, K, Tsukasaki, K, Kohno, T, Chen, Y, Kamihira, S \& Tomonaga, M (1996) Features of the cytokines secreted by adult T cell leukemia (ATL) cells. Leuk Lymphoma, 21, 5-6, 443-7, 1042-8194.

Yamada, Y, Sugawara, K, Hata, T, Tsuruta, K, Moriuchi, R, Maeda, T, Atogami, S, Murata, K, Fujimoto, K, Kohno, T, Tsukasaki, K, Tomonaga, M, Hirakata, Y \& Kamihira, S (1998) Interleukin-15 (IL-15) can replace the IL-2 signal in IL-2-dependent adult Tcell leukemia (ATL) cell lines: expression of IL-15 receptor alpha on ATL cells. Blood, 91, 11, 4265-72, 0006-4971.

Yamamoto, K, Quelle, FW, Thierfelder, WE, Kreider, BL, Gilbert, DJ, Jenkins, NA, Copeland, NG, Silvennoinen, O \& Ihle, JN (1994) Stat4, a novel $\gamma$ interferon activation sitebinding protein expressed in early myeloid differentiation. Mol Cell Biol, 14, 7, 43429.

Yang, L, Zhao, T, Shi, X, Nakhaei, P, Wang, Y, Sun, Q, Hiscott, J \& Lin, R (2009) Functional analysis of a dominant negative mutation of interferon regulatory factor 5. PLoS One, 4, 5, e5500, 1932-6203.

Yasunaga, J, Lin, FC, Lu, X \& Jeang, KT (2011) Ubiquitin-specific peptidase 20 (USP20) targets TRAF6 and HTLV-1 Tax to negatively regulate NF- $\{\kappa\} B$ signaling. J Virol, 1098-5514.

Zhang, J, Yamada, O, Kawagishi, K, Araki, H, Yamaoka, S, Hattori, T \& Shimotohno, K (2008) Human T-cell leukemia virus type 1 Tax modulates interferon-alpha signal transduction through competitive usage of the coactivator CBP/p300. Virology, 379, 2, 306-13, 1096-0341.

Zhang, S \& Kaplan, MH (2000) The p38 mitogen-activated protein kinase is required for IL12-induced IFN- $\gamma$ expression. J Immunol, 165, 3, 1374-80.

Zhao, T, Yasunaga, J, Satou, Y, Nakao, M, Takahashi, M, Fujii, M \& Matsuoka, M (2009) Human T-cell leukemia virus type $1 \mathrm{bZIP}$ factor selectively suppresses the classical pathway of NF-кB. Blood, 113, 12, 2755-64, 1528-0020.

Zhong, Z, Wen, Z \& Darnell, JE, Jr. (1994) Stat3 and Stat4: members of the family of signal transducers and activators of transcription. Proc Natl Acad Sci U S A, 91, 11, 4806-10. 


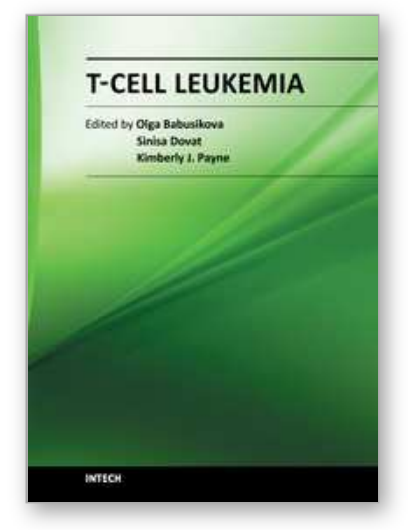

\author{
T-Cell Leukemia \\ Edited by Dr Olga Babusikova
}

ISBN 978-953-307-400-9

Hard cover, 234 pages

Publisher InTech

Published online 26, October, 2011

Published in print edition October, 2011

The purpose of this book is to provide a comprehensive review of the scientific advances in T-cell malignancies and to highlight the most relevant findings that will help the reader understand both basic mechanisms of the disease and future directions that are likely to lead to novel therapies. In order to assure a thorough approach to these problems, contributors include basic scientists, translational researchers and clinicians who are experts in this field. Thus, the target audience for this book includes both basic scientists who will use this book as a review of the advances in our fundamental knowledge of the molecular mechanisms of T-cell malignancies, as well as clinicians who will use this book as a tool to understand rationales for the development of novel treatments for these diseases.

\title{
How to reference
}

In order to correctly reference this scholarly work, feel free to copy and paste the following:

Takehiro Higashi, Takefumi Katsuragi, Atsushi Iwashige, Hiroaki Morimoto and Junichi Tsukada (2011). Constitutive Activation of the JAK/STAT and Toll-Like Receptor Signaling Pathways in Adult T-Cell Leukemia/Lymphoma, T-Cell Leukemia, Dr Olga Babusikova (Ed.), ISBN: 978-953-307-400-9, InTech, Available from: http://www.intechopen.com/books/t-cell-leukemia/constitutive-activation-of-the-jak-stat-and-tolllike-receptor-signaling-pathways-in-adult-t-cell-le

\section{INTECH}

open science | open minds

\author{
InTech Europe \\ University Campus STeP Ri \\ Slavka Krautzeka 83/A \\ 51000 Rijeka, Croatia \\ Phone: +385 (51) 770447 \\ Fax: +385 (51) 686166 \\ www.intechopen.com
}

\author{
InTech China \\ Unit 405, Office Block, Hotel Equatorial Shanghai \\ No.65, Yan An Road (West), Shanghai, 200040, China \\ 中国上海市延安西路65号上海国际贵都大饭店办公楼 405 单元 \\ Phone: +86-21-62489820 \\ Fax: +86-21-62489821
}


(C) 2011 The Author(s). Licensee IntechOpen. This is an open access article distributed under the terms of the Creative Commons Attribution 3.0 License, which permits unrestricted use, distribution, and reproduction in any medium, provided the original work is properly cited. 